\title{
Ultrasonography in Diagnosis and Follow-Up of Temporal Arteritis: An Update
}

\author{
Giovanni Ciancio, Marco Bruschi and Marcello Govoni \\ Rheumatology Unit Department \\ of Clinical and Experimental Medicine- \\ University of Ferrara Azienda Ospedaliero, \\ Universitaria Sant'Anna, Ferrara \\ Italy
}

\section{Introduction}

Giant cell arteritis (GCA), also known as temporal arteritis (TA) is a relatively frequent primary systemic vasculitis affecting large and medium-sized arteries, in particular aorta and its main branches (Hunder, 2000). It occurs, by definition, in patients older than fifty with a peak between 70 and 80 years. The disease primarily affects whites, specifically those of northern European descent, and the highest worldwide incidence is reported to be in southern Norway with 32.8 per 100.000 people over the age of 50 affected (Richards et al., 2010). GCA affects women 2-3 times more commonly than men (Richards et al., 2010).

The spectrum of clinical manifestations associated with TA includes a wide combination of symptoms and signs, ranging from tender and swollen temporal arteries, headache and jaw claudication to systemic and musculoskeletal symptoms such as fatigue, weight loss, lowgrade fever, polymyalgia rheumatica, arthralgias and tenosynovitis (Hunder, 2000). Irreversible visual loss secondary to ischemic optic neuropathy is the most serious and dreaded complication, so prompt diagnosis and treatment are mandatory to prevent it (Gonzalez-Gay et al., 2005; Hunder, 2000).

\subsection{Diagnosis of GCA: Current issues}

Although a rapid and non-invasive diagnosis of TA would be desirable, it still remains a challenge for clinicians. History, typical clinical findings and elevation of acute phase reactants are usually sufficient to induce the suspicion for TA but they are insufficient to give diagnostic certainty. The American College of Rheumatology classification criteria (ACRC) for GCA (Hunder et al., 1990) help to distinguish TA from other primary vasculitides for research purposes, but they have significant limitations in clinical diagnosis (Rao et al., 1998). Therefore, temporal artery biopsy (TAB) is still considered the gold standard because of its high specificity and it is currently recommended in all suspected cases of TA (Drehmer et al., 2005). At present, segments of at least $2.5 \mathrm{~cm}$ are considered adequate to reduce - but not to completely avoid - the risk of skip lesions (Gonzalez-Gay, 2005). Since histology can be influenced by corticosteroids, TAB should be performed before 
starting therapy (Ray-Chaudhuri et al., 2002) but in most cases it is too hazardous to wait until biopsy is performed, thus steroids are usually started as soon as GCA is clinically suspected (Borg \& Dasgupta, 2009). After starting high dose of corticosteroids, TAB can remain informative even for up to 4-6 weeks (Achkar et al., 1994; Ray-Chaudhuri et al., 2002) but it should be performed no later than two weeks ( Borg \& Dasgupta, 2009; Warrington \& Matteson, 2007).

However TAB implies a number of problems. It is an invasive procedure that may lead to some complications (Bhatti \& Goldstein, 2001; Haist, 1985; Siemssen, 1987; Slavin, 1986) and it is usually available much too late to influence therapeutic decision (Nesher et al., 2004). Moreover, TAB may result negative in up to $10 \%-44 \%$ of patients (Hall et al., 1983; Schmidt, 2006) and in these cases patients should undergo controlateral TAB if clinical suspicion of GCA is high (Gonzalez-Gay, 2005).

On this background, new non-invasive vascular diagnostic techniques, such as ultrasound (US) and vascular magnetic resonance imaging (MRI), have gained in the last years a growing interest and an increasing importance in clinical diagnosis (Schmidt, 2004). In particular US, whose resolution with regard to superficial anatomical structures is superior to that of MRI, can provide an excellent evaluation of vessel anatomy and inflammatory alterations (Gonzalez-Gay et al., 2006; Schmidt \& Blockmans, 2005).

Regular use of these non invasive imaging modalities in the diagnosis of GCA instead of $\mathrm{TAB}$ is currently a debated issue.

\section{Ultrasonography in TA}

With the availability of high-resolution Color Doppler (CD) and the high-frequency transducers, ultrasonography has became an increasingly powerful tool also for rheumatologists (Grassi et al., 2004). High-frequency probes have a resolution of about $0.1 \mathrm{~mm}$ and provide an optimal examination of joints, muscles and tendons (Grassi et al., 2004; Schmidt, 2004). CD and Color Duplex US (CDUS) offer further benefits over conventional Doppler US. CD integrates Doppler effect in the greyscale image as a colour signal and allows an accurate study of both small vessels and large arteries (Romera-Villegas et al., 2004; Schmidt, 2004; Schmidt \& Blockmans, 2005). The sensitivity of $C D$ in detecting the small vessels is even more enhanced by the application of Power Doppler, which is extremely useful in highlighting the slow blood flow and, consequently, it allows to study articular, periarticular and peritendinous inflamed tissues more accurately (Grassi et al., 2004; Schmidt, 2004). In addition CD is able to depict the wall of large arteries and the associated inflammatory changes in detail, thus appearing very useful in the diagnostic assessment of vasculitis (Kissin \& Merkel, 2004) compared to conventional continuous-wave Doppler, which cannot provide anatomical images (Dany et al., 1989; Kelley, 1978; Puechal et al., 1995; Vinckier et al., 1989). CDUS offers further benefits over CD. Through a combination of real-time imaging and Doppler sonography, it shows at the same time anatomical images with colour signals and pulsed-wave Doppler curves, allowing an evaluation of the velocity of blood flow by the integration of Doppler shift frequency in combination with an angle correction programme (Schmidt \& Gromnica-Ihle, 2005). Thus alterations like stenosis and occlusions, that frequently occur in acute temporal arteritis, can be evaluated more easily (Schmidt \& Gromnica-Ihle, 2005). 


\subsection{Sonographic features}

The usefulness of CD and CDUS in the diagnosis of TA was demonstrated in 1995 by Schmidt and colleagues (Schmidt et al., 1995). They first described in temporal arteries of patients affected by acute TA the 'halo' sign, ascribed to oedematous wall swelling and characterized by a hypoechoic and circumferential wall thickening localized around the perfused lumen with a diameter ranging between 0.3 and $2 \mathrm{~mm}$ (Schmidt et al., 1995) (Fig.1,2).

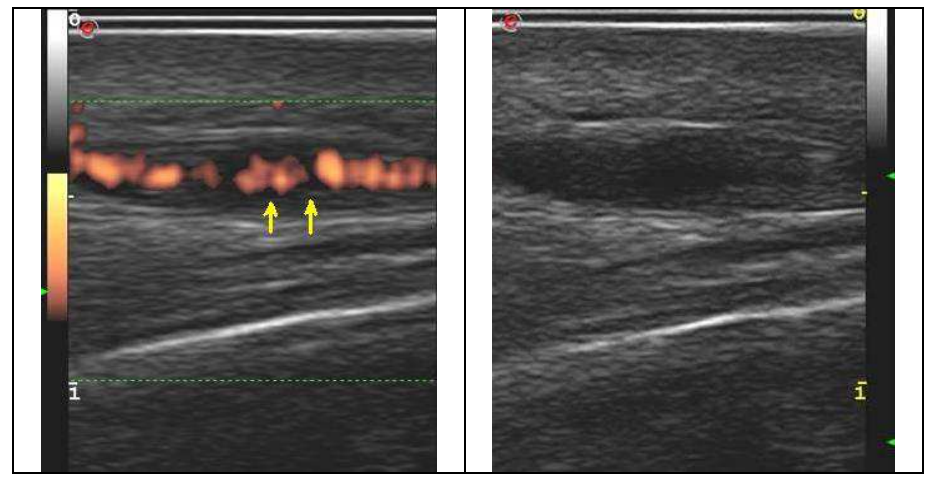

Fig. 1. US Color Doppler of the left parietal ramus in acute TA. Longitudinal plane. Very high-frequency transducer at $18 \mathrm{MhZ}$ (My Lab 70- Esaote). Hypoechoic dark area ("halo") is indicated by the yellow arrows (left side). On the right side: the same arterial segment in the greyscale.

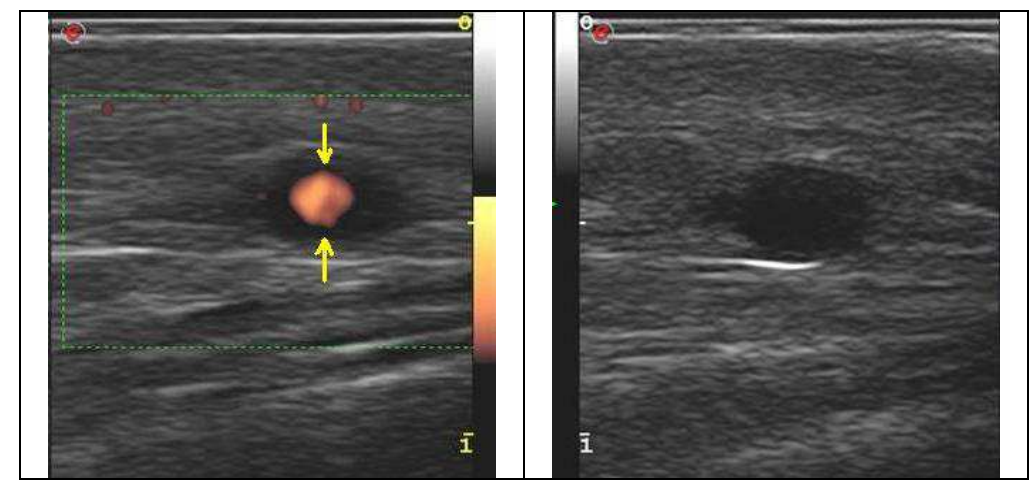

Fig. 2. US Color Doppler of the right distal third of the common superficial temporal artery in acute TA. Transverse plane. Very high-frequency transducer at $18 \mathrm{MhZ}$ (Esaote-My Lab 70). Hypoechoic dark area ("halo") is indicated by the yellow arrows (right side). On the right side: the same arterial segment in the greyscale.

The other two parameters considered relevant for the diagnosis of TA are stenosis and occlusion of the arteries. Stenosis, characterized by a narrowing of the vessel lumen, has been defined as a segmental increase in blood flow velocity and two time higher than in the area before the stenosis. Other ancillary US features are turbulence of the flow with reduced 
velocity behind the area of the stenosis and the persistence of the colour signal during diastole (Schmidt et al., 1995). Acute temporal artery occlusion is revealed by the complete absence of colour signals in a segment of temporal artery (Schmidt et al., 1995).

\subsection{Sensitivity and specificity of CDUS in TA}

In 1997, Schmidt and coll. published data on the sensitivity and specificity of CDUS in their series of 30 patients with active TA compared with 82 controls, with clinical diagnosis and biopsy as reference standard (Schmidt et al., 1997). Diagnosis of TA was confirmed by biopsy in 21 of the 30 patients. Hypoechoic halo was evidenced in 22/30 patients with TA; stenoses or occlusions in 24/30; stenoses, occlusions, or a halo in $28 / 30$. On the contrary, no halo was evidenced in the 82 controls without TA but $6 / 82$ had stenoses or occlusions. With regard to clinical diagnosis, sensitivity and specificity for the halo were $73 \%$ and $100 \%$, whilst for stenosis and/or occlusion were $80 \%$ and $93 \%$, respectively. With regard to histology, sensitivity and specificity for the halo resulted to be $76 \%$ and $92 \%$, while for stenosis and/or occlusion were $86 \%$ and $88 \%$, respectively. Noteworthy, if halo, stenosis and occlusion were considered together, sensitivity resulted higher both $v$ s clinical diagnosis (93\%) and vs histology (95\%).

These results have been confirmed by the same authors in a larger study on 101 patients with acute TA vs 650 controls (Schmidt \& Gromnica-Ihle, 2003). Sensitivity resulted low and specificity high vs clinical diagnosis and histology when the halo was considered alone, while sensitivity became significantly higher when halo, stenosis and occlusion were considered together (Schmidt \& Gromnica-Ihle, 2003). Stenosis alone demonstrated a very low sensitivity in TA because it was commonly found even in elderly patients without TA, since they are usually affected by arteriosclerosis (Schmidt et al., 1997; Schmidt \& GromnicaIhle, 2003, 2005). Conversely acute occlusions, although less frequent than stenosis, were more specific for TA being rarely found in patients without TA (Schmidt et al., 1997; Schmidt \& Gromnica-Ihle, 2003, 2005)

Since the first description (Schmidt et al., 1997), several studies have been published on the diagnostic value of CDUS in TA with similar results (Aschwanden et al., 2010; Bley et al., 2008; Ghinoi et al., 2008; Houtman et al., 2008; Karahaliou et al., 2006; Lesar et al., 2002; Maldini et al., 2010; Morinobu et al., 2011; Murgatroyd et al., 2003; Nesher et al., 2002; Perez Lopez et al., 2009; Pfadenhauer \& Weber, 2003; Reinhard et al., 2004; Romera-Villegas et al., 2004; Salvarani et al., 2002; Schmidt, 2000; Schmidt \& Gromnica-Ihle, 2003; Suelves et al., 2010).

In the 2005, Karassa and coll. published a meta-analysis aimed to review the diagnostic value of CDUS in GCA (Karassa et al., 2005). The authors selected the most important studies published up to 2004. In all these reports, biopsy and the ACRC were used as the reference standard. The weighted sensitivity of halo sign resulted $69 \%$ (vs biopsy) and 55\% (vs ACRC), while the specificity was $82 \%$ (vs biopsy) and $94 \%$ (vs ACRC criteria). Stenosis or occlusion showed quite a similar sensitivity ( $68 \%$ vs biopsy and $66 \%$ vs ACRC criteria). This analysis confirmed the utility of CDUS in diagnosing GCA and the high specificity of the halo sign, the detection of which strongly supports the diagnosis of TA. However most of the studies included in this meta-analysis were small, of modest quality and with a considerable degree of heterogeneity.

Two further meta-analysis were published more recently in 2010 (Arida et al., 2010; Ball et al., 2010). In the first one, the sensitivity and specificity of the halo sign versus the ACRC as 
a reference standard were examined. (Arida et al., 2010). Eight prospective studies, through December 2009, fulfilling technical quality criteria for ultrasound and involving 575 patients were finally selected. Compared with final diagnosis, sensitivity and specificity resulted of $68 \%$ and $91 \%$ for the presence of unilateral halo, and of $43 \%$ and $100 \%$ for bilateral halo, respectively.

In the second meta-analysis performed by Ball and coll., (Ball et al., 2010), all studies in english language published up to 2009 with a minimum of 5 patients and using TA biopsy and/or ACRC criteria as the reference standard were included. When the halo sign was compared with TA biopsy, the weighted sensitivity and specificity resulted $75 \%$ and $83 \%$ respectively. When the halo sign was compared with ACR criteria, the weighted sensitivity and specificity resulted $69 \%$ and $89 \%$ respectively. This study confirms the high specificity but also evidenced the higher sensitivity of the halo sign, that may reflect both the improvement of the duplex machines and the increased expertise of the ultrasonographers (Ball et al., 2010). Very interestingly, when halo, stenosis and occlusion were considered together, sensitivity further increased in comparison to TA biopsy and ACR criteria to $83 \%$ and $78 \%$, respectively (Ball et al., 2010) (Table 1)

\begin{tabular}{|c|c|c|c|c|c|c|c|}
\hline \multirow[t]{2}{*}{ CDUS alterations } & \multirow[t]{2}{*}{$\begin{array}{l}\text { Reference } \\
\text { standard }\end{array}$} & \multicolumn{2}{|c|}{$\begin{array}{c}\text { Karassa and } \\
\text { coll. }\end{array}$} & \multicolumn{2}{|c|}{ Arida and coll. } & \multicolumn{2}{|c|}{ Ball and coll. } \\
\hline & & $\begin{array}{c}\text { Sens. } \\
(\%)\end{array}$ & $\begin{array}{c}\text { Spec. } \\
(\%)\end{array}$ & $\begin{array}{c}\text { Sens. } \\
(\%)\end{array}$ & $\begin{array}{c}\text { Spec. } \\
(\%)\end{array}$ & $\begin{array}{c}\text { Sens. } \\
(\%)\end{array}$ & $\begin{array}{c}\text { Spec. } \\
(\%)\end{array}$ \\
\hline $\mathrm{H}$ & TAB & 69 & 82 & & & 75 & 83 \\
\hline $\mathrm{S} / \mathrm{O}$ & TAB & 68 & & & & & \\
\hline $\mathrm{H}+\mathrm{S}+\mathrm{O}$ & TAB & & & & & 83 & 82 \\
\hline $\mathrm{H}$ & ACRC & 55 & 94 & $\begin{array}{c}68 \\
\text { (43 if } \\
\text { bilat.) }\end{array}$ & $\begin{array}{c}91 \\
\text { (100 if } \\
\text { bilat.) }\end{array}$ & 69 & 89 \\
\hline $\mathrm{S} / \mathrm{O}$ & ACRC & 66 & & & & & \\
\hline $\mathrm{H}+\mathrm{S}+\mathrm{O}$ & ACRC & & & & & 78 & 88 \\
\hline
\end{tabular}

Table 1. CDUS signs vs references standard in the 3 meta-analysis. TA: temporal artery; ACRC: American College of Rheumatology Criteria. H: Halo; S: Stenosis; O: Occlusion. TAB: Temporal Artery Biopsy.

In summary, all these data confirm that the dark halo is the most specific CDUS sign in GCA, so its detection strongly supports a diagnosis of TA in patients with typical clinical signs. On the other hand, sensitivity of halo is lower than specificity, so the absence of a halo does not exclude TA. If halo, stenosis and occlusions are considered together, the sensitivity of CDUS is higher and comparable to histology.

Interestingly, in the study of Karahaliou (Karahaliou et al., 2006) it has been shown that the presence of a bilateral halo sign had a 100\% specificity for the diagnosis of TA; this observation led the authors to conclude that bilateral "halo sign" may be substitutive of TA biopsy.

The results of a recent study by Maldini and coll. led to less enthusiastic conclusions about the real value of US in GCA (Maldini et al., 2010). Characteristics of US findings with continuouswave Doppler or CDUS of temporal arteries was retrospectively evaluated and compared with 
biopsy and clinical diagnosis. Halo sign showed 100\% specificity for GCA but only $10 \%-17 \%$ sensitivity; stenoses or occlusions appeared to have low diagnostic power. These data led the authors to conclude that US in GCA is neither an effective substitute for biopsy nor a reliable screening test to decide which patients can be safely spared from TAB.

\subsection{US in follow-up of TA}

In our experience, CDUS resulted very helpful in the diagnostic work-up, in identifying the best target segment to biopsy and in follow-up of patients with TA (Ciancio et al, 2009; Fotinidi et al, 2011).

We performed bilateral CDUS examination to check for the halo thickness, erythrocyte sedimentation rate (ESR) and C-reactive protein (CRP) in a group of 25 patients at baseline and after 2, 4 and 6 weeks. Both sensitivity and specificity for the halo resulted very high $(100 \%)$ when compared to clinical diagnosis and biopsy. During follow-up, the halo thickness in all the 25 patients disappeared 2-weeks after starting corticosteroids (Fig. 3) and

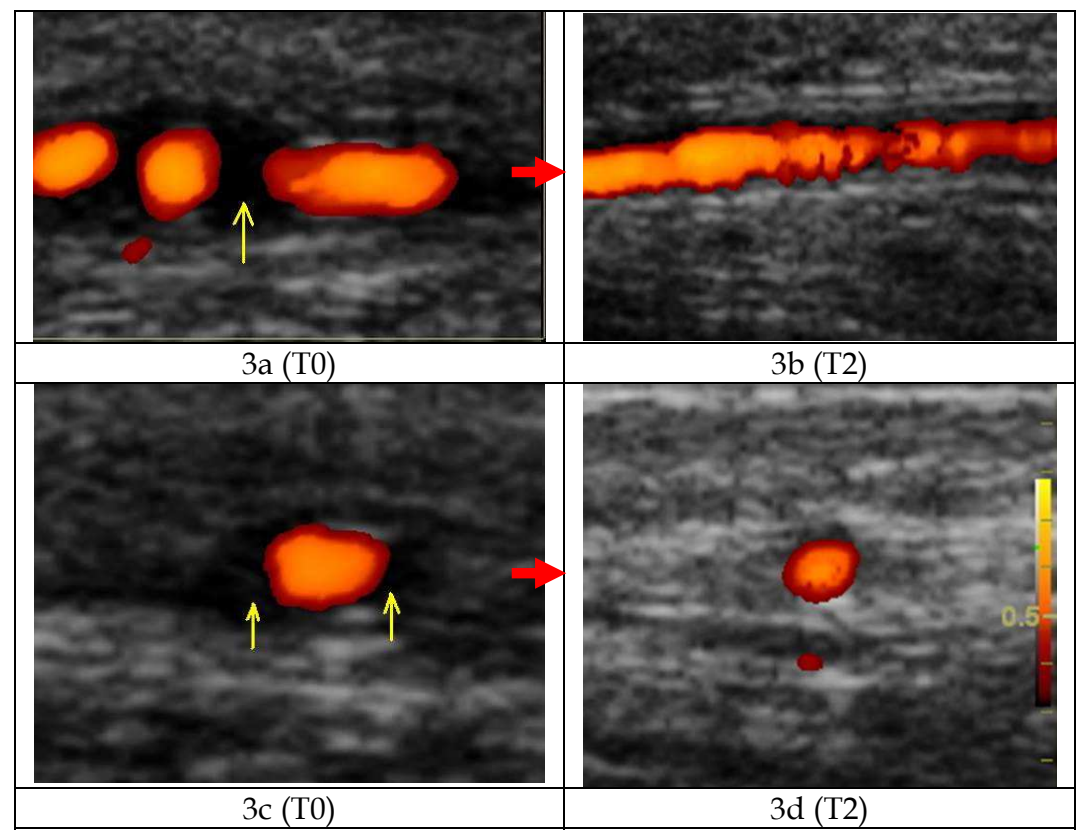

Fig. 3. Left parietal ramus of the superficial temporal artery in a patient with acute GCA at baseline (T0: on the left) and after two weeks of corticosteroid therapy (T2: on the right). High-frequency transducer at $12 \mathrm{MhZ}$ (Logic 5 Pro-GE)

3a. Longitudinal plane. Baseline (T0). The hypoechoic (black) area is indicated by the yellow arrows

3b.Longitudinal plane. Complete remission of the halo after two weeks (T2) of corticosteroids

3c. Transverse Plane of the same segment. Baseline (T0).The hypoechoic (black) area is indicated by the yellow arrows

3d. Transverse Plane. Complete remission of the halo after two weeks (T2) of corticosteroids 
this modification antedated the normalization of both ESR and CRP thus suggesting that CDUS may allow a better monitoring of clinical course and can guide a more careful tapering of glucocorticoid therapy (Chart 1). Obviously, this observation needs further confirmations in larger series since the role of CDUS in follow-up of TA is still currently considered rather doubtful and less useful for monitoring disease activity than the patient's history and/or ESR (Schmidt, 2004). Furthermore, in extracranial GCA the sonographic appearance of the arterial wall has not been validated yet as a reliable parameter for the assessment of disease activity (Tato \& Hoffmann, 2008). Although the halo decreases during treatment, some degree of thickening of the arterial wall and stenosis can persist even in patients in complete remission, and complete recanalization of occluded arterial segments does not always occur (Schmidt \& Blockmans, 2005; Tato e\& Hoffmann, 2008).

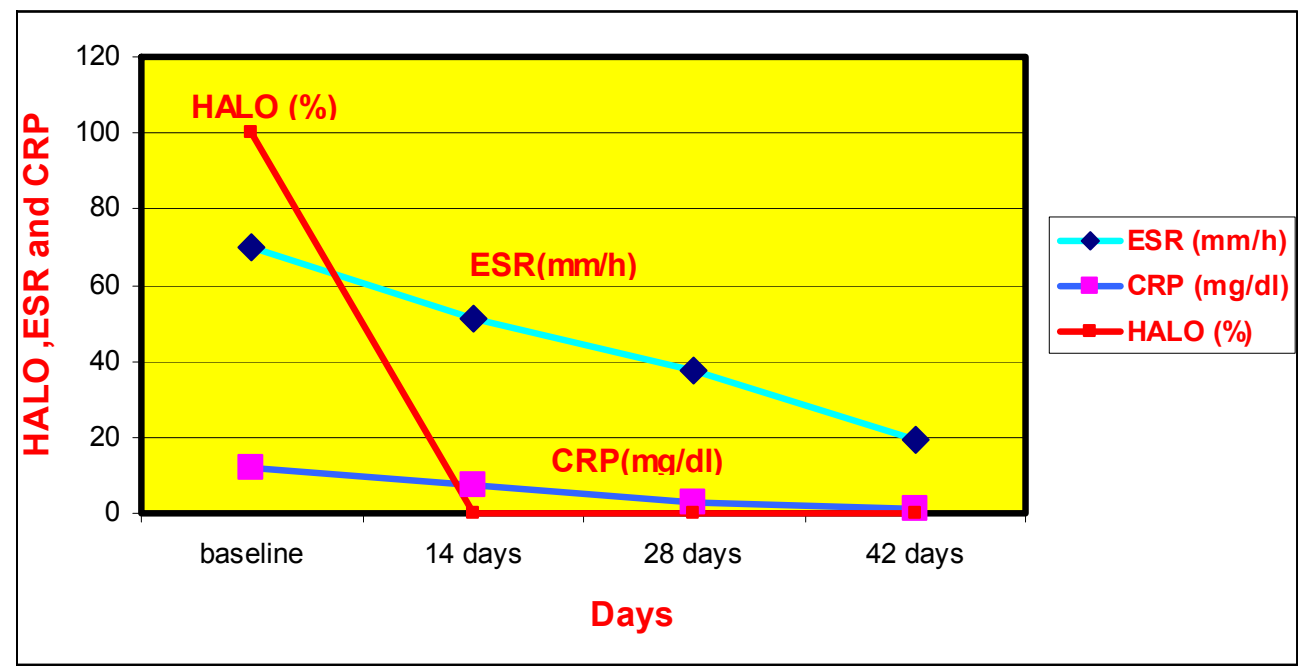

Chart 1. Variation of the monitored parameters (ESR and CRP vs HALO) in the 25 patients with GCA. ESR and CRP: mean value among the 25 patient at each time point.

ESR: erythrocyte sedimentation rate. CRP: C-reactive protein

\subsection{Examination technique}

Detailed technical aspects of the examination methodology have been described in an excellent review by Schmidt (Schmidt, 2004). Briefly, a high quality CD US equipment and standardised US machine adjustments, the use of linear probe with high frequency (>8 $\mathrm{MHz}$ ) and a good experience of the operator are indispensable to adequately perform CDUS of temporal arteries.

\subsubsection{US equipment}

Excellent equipment is currently available and provided by different companies. However, even the best is likely to be ineffective for an adequate depiction of temporal arteries alterations if right machine settings are missing. A prerequisite to appropriately perform $\mathrm{CD}$ examination of temporal arteries is the availability of high frequency ( $>8 \mathrm{MHz})$ linear transducers. The availability of modern probes with frequencies of up to $15 \mathrm{MHz}$ has greatly 
increased the resolution power for the evaluation of surface anatomical layers. Depending on the individual equipment, a too high frequency for the colour image may even reduce the sensitivity for the colour, and if grey scale and colour gains are too high or too low, it is possible to overlook hypoechoic areas or to generate false hypoechoic areas, respectively (Schmidt, 2004). Even the colour sample steering is important; it should have an angle of 20$30^{\circ}$ when a branch parallel to the probe is examined, otherwise the colour signal would not be adequate (Schmidt, 2004). Again, pulse repetition frequency (PRF) should be carefully regulated to 2-2.5 KHz. Because of the high blood flow velocities, colour Doppler should be preferred to power Doppler since the latter may miss stenoses.

\subsubsection{Experience of the sonographer}

In order to properly examine temporal arteries, a good experience with vascular US should be warranted by a trained operator and a perfect knowledge of the US appearance of normal temporal arteries is mandatory. Artefacts may occur and the operator must be very familiar with them. It has been recommended that a minimum of 50 normal temporal arteries examination should be performed before starting to evaluate patients with suspected GCA (Schmidt, 2004). Recent experiences with standardized training programs to allow rheumatologists to learn the technique for US examination of the temporal arteries have shown encouraging results by proving effective and well accepted by the trainees (De Miguel et al., 2009)

\subsection{Limits of CDUS in TA}

False-positive and false-negative halos may be seen when performing CDUS. If the common superficial TA has an accompanying vein in which no flow is seen, this can be erroneously checked for a halo (Schmidt, 2000). False-positive halos are also seen in malignant and infectious diseases (Nesher et al., 2002).On the contrary, halo can be missed if a stronger colour intensity covering the inflamed wall is employed (Schmidt, 2000). Moreover, about 10 per cent of patients with a positive biopsy have normal duplex imaging as a result of very low inflammatory infiltrate possibly due both to mild disease or prolonged corticosteroid treatment (Schmidt, 2004; Weyand \& Goronzy, 2003;). It has been demonstrated that CDUS findings in active TA do not correlate with occurrence and severity of ophthalmic complications (Schmidt et al., 2009). Furthermore, CDUS is not able to differentiate between GCA and other vasculitis that can involve temporal arteries, as it can occur in Wegener's granulomatosis, Churg-Strauss syndrome and microscopic polyangiitis (Schmidt \& Gromnica-Ihle, 2005).

\subsection{US findings in extracranial GCA}

CDUS can also be very useful for diagnosis, assessment of severity and follow-up when extracranial large arteries are involved in GCA. (Aschwanden et al., 2010; Kolossvary et al., 2005; Reinhard et al., 2003; Schmidt et al., 2002; Schmidt et al., 2008;). In brachial, subclavian or axillary arteries, CDUS has been shown to be able to demonstrate the typical signs of vascular inflammation such as concentric and hypoechogenic wall thickening of arterial segments, the narrowing of the arterial lumen or a hypoechogenic occlusion. (Kolossvary et al., 2005; Schmidt et al., 2008). CDUS signs in association with clinical symptoms and elevated laboratory markers of systemic inflammation can be considered diagnostic for large-vessel vasculitis making it unnecessary to use of conventional angiography (Tato \& 
Hoffmann, 2008). With regard to the involvement of lower limbs in GCA, CDUS semeiology of femoropopliteal and crural arteries appears to be the same as in the vessels of the upper limbs (Aschwanden et al., 2010; Schmidt et al., 2002; Tato \& Hoffmann, 2006;)

\section{Other tools for the diagnosis of GCA}

In recent years, other imaging techniques have been proved useful in the diagnosis of TA, such as magnetic resonance imaging (MRI), 18F-fluorodeoxyglucose positron emission tomography (FDG-PET), single-photon emission computed tomography (SPECT) and computed tomography (CT). High-resolution contrast-enhanced MRI and angio-MRI have proved useful in visualizing the involvement of temporal arteries and/or other large arteries such as aorta in extracranial GCA (Bley et al., 2005; Narvaez et al., 2005). MRI was also able to evidence isolate inflammation of the occipital arteries, with sparing of the temporal arteries (Bley et al., 2005).

The utility of FDG-PET in evaluating the active lesions of large arteries in patients with systemic vasculitis including GCA has recently been demonstrated(Schmidt e Blockmans, 2005). However, PET is not suitable for the assessment of temporal arteries (Schmidt \& Blockmans, 2005) but it has proven useful in assessing disease activity during therapy in extracranial GCA (Walter et al., 2005).

In a pilot study, SPECT revealed positive findings in temporal arteries of nine patients with active temporal arteritis (Reitblat et al., 2003). In selected cases, angiography and CT may still have a role in investigating the involvement of large extracranial arteries in GCA (Stanson, 2000).

\section{Conclusion}

Although, to date, biopsy remains the gold standard for diagnosis of TA, CDUS may be considered a very useful tool. It is inexpensive, non-invasive, reproducible and easy-toperform. Dark halo is the most specific CDUS sign in GCA, so its detection strongly supports a diagnosis of TA in patients with typical clinical signs. Sensitivity of halo is lower than specificity, so the absence of a halo does not exclude TA but if halo, stenosis and occlusions are simultaneously detected sensitivity of CDUS becomes high and comparable to histology. Finally, detection of the halo could allow a guided biopsy with an increased probability to avoid false negative results due to skip lesions. Therefore, CDUS should precede TA biopsy in all patients with suspected GCA. After initiating therapy, the disappearance of the halo has proved to be more sensitive than ESR and CRP. If confirmed by other studies, CDUS could be usefully employed also in follow-up allowing a better monitoring and tapering of glucocorticoid therapy. The contribution of CDUS is useful also for diagnosis, assessment of severity and follow-up in extracranial GCA.

Some limits of US evaluation should be well kept in mind, such as the possibility of falsepositive and false-negative halos, the lack of correlations with ophthalmic complications and the inability to differentiate GCA by other vasculitis. The heavy dependence on operator expertise is another critical point to be considered.

Even if CDUS has gained an emerging role in the diagnostic workup of GCA, larger studies are needed in the near future to verify the possibility that this technique may really replace the TAB in the diagnostic work-up of TA and that it could be a reliable tool in the follow up evaluation. 


\section{Acknowledgments}

We are very grateful to Prof. Francesco Trotta for his valuable advice in the preparation and review of the work.

\section{References}

Achkar, AA., Lie, JT., Hunder, GG., O'Fallon, WM. \& Gabriel, SE. (1994). How does previous corticosteroid treatment affect the biopsy findings in giant cell (temporal) arteritis? Annals of Internal Medicine, Vol. 120, No 12, (June 1994), pp. 987-92, ISSN 0003-4819

Arida, A., Kyprianou, M., Kanakis, M. \& Sfikakis, PP. (2010). The diagnostic value of ultrasonography-derived edema of the temporal artery wall in giant cell arteritis: a second meta-analysis. BMC Musculoskeletal Disorders, Vol. 11, (March 2010), p. 44, ISSN 1471-2474

Aschwanden, M., Kesten, F., Stern, M., Thalhammer, C., Walker, UA., Tyndall, A., Jaeger, KA., Hess, C. \& Daikeler, T. (2010). Vascular involvement in patients with giant cell arteritis determined by duplex sonography of $2 \times 11$ arterial regions. Annals of the Rheumatic Diseases, Vol. 69, No. 7, (Jul 2010), pp. 1356-9, ISSN 1468-2060

Ball, EL., Walsh, SR., Tang, TY., Gohil, R. \& Clarke, JM. (2010). Role of ultrasonography in the diagnosis of temporal arteritis. Br J Surg, Vol. 97, No. 12, (Dec 2010), pp. 176571, ISSN 1365-2168

Bhatti, MT. \& Goldstein, MH. (2001). Facial nerve injury following superficial temporal artery biopsy. Dermatologic Surgery, Vol. 27, No.1, (Jan 2001), pp. 15-7, ISSN 1076-0512

Bley, TA., Wieben, O., Uhl, M., Thiel, J., Schmidt, D. \& Langer, M. (2005). High-resolution MRI in giant cell arteritis: imaging of the wall of the superficial temporal artery. American Journal of Roentgenology, Vol. 184, No. 1 (Jan 2005), pp. 283-7, ISSN 0361-803X

Bley, TA., Reinhard, M., Hauenstein, C., Markl, M., Warnatz, K., Hetzel, A., Uhl, M., Vaith, P.\& Langer M. (2008). Comparison of duplex sonography and high-resolution magnetic resonance imaging in the diagnosis of giant cell (temporal) arteritis. Arthritis and Rheumatism, Vol. 58, No. 8, (Aug 2008), pp. 2574-8, ISSN 0004-3591

Borg, FA.\& Dasgupta, B. Treatment and outcomes of large vessel arteritis.(2009). Best Practice \& Research Clinical Rheumatology, Vol. 23, No 3, (Jun 2009), pp. 325-37, ISSN 1532-1770

Ciancio, G., Colina, M., De Leonardis, F., Foschi, V., Govoni, M. \& Trotta F. (2009). Colour duplex ultrasonography in the diagnosis and management of giant cell arteritis. Arthritis Rheumatism, Vol. 60, No. 10 (Supplement), (November 2009), p.672

Dany, F., Liozon, F., Chaumont, P., Chastang, A., Lacroix, P., Catanzano, R. \& Christides C. (1989). Sensitivity and specificity of temporal Doppler in Horton's disease. Journal des maladies vasculaires, Vol. 14, Suppl. C, (1989), pp. 104-8, ISSN 0398-0499

De Miguel, E., Castillo, C., Rodriguez, A. \& De Agustin, JJ. (2009). Learning and reliability of colour Doppler ultrasound in giant cell arteritis. Clinical and Experimental Rheumatology, Vol.. 27, No. 1, Suppl 52, (Jan-Feb 2009), pp. S53-8,. ISSN 0392-856X

Drehmer, TJ., Khanna, D., Markert, RJ. \& Hawkins, RA. (2005). Diagnostic and management trends of giant cell arteritis: a physician survey. Journal of Rheumatology, Vol. 32, No. 7, (Jul 2005), pp. 1283-9, ISSN 0315-162X 
Fotinidi, M., Farina, I., Bortoluzzi, A., Galuppi, E., Giacuzzo, S., Bruschi, M., Occhionorelli, S., Giusto, L., Vanini, A., Ciancio, G. \& Govoni, M. (2011). Colour duplex ultrasonography in diagnostic assessment and follow-up of giant cell arteritis. Annals of the Rheumatic diseases. Abstract Book, European League Against Rheumatism (EULAR) Congress. London. Vol. 70, (Suppl 3), AB0976, (May 2011)

Ghinoi, A., Zuccoli, G., Nicolini, A., Pipitone, N., Macchioni, L., Bajocchi, GL., Nicoli, F., Silingardi, M., Catanoso, MG., Boiardi, L. \& Salvarani C. (2008). 1T magnetic resonance imaging in the diagnosis of giant cell arteritis: comparison with ultrasonography and physical examination of temporal arteries. Clinical and experimental Rheumatology Vol. 26, No. 3, Suppl 49, (May-Jun 2008), pp. S76-80, ISSN 0392-856X

Gonzalez-Gay, MA. The diagnosis and management of patients with giant cell arteritis. (2005). Journal of Rheumatology, Vol. 32, No. 7, (Jul 2005), pp. 1186-8, ISSN 0315-162X

Gonzalez-Gay, MA., Barros, S., Lopez-Diaz, MJ., Garcia-Porrua, C., Sanchez-Andrade, A. \& Llorca J. (2005). Giant cell arteritis: disease patterns of clinical presentation in a series of 240 patients. Medicine (Baltimore), Vol. 84, No. 5, (Sep 2005), pp. 269-76, ISSN 0025-7974

Gonzalez-Gay, MA., Garcia-Porrua, C. \& Miranda-Filloy JA. (2006). Giant cell arteritis: diagnosis and therapeutic management. Current Rheumatology Reports, Vol. 8, No. 4, (Aug 2006), pp. 299-302, ISSN 1523-3774

Grassi, W., Filippucci, E. \& Busilacchi P. (2004). Musculoskeletal ultrasound. Best Practice \& Research Clinical Rheumatology, Vol. 18, No. 6, (Dec 2004), pp. 813-26, ISSN 15216942

Haist SA. Stroke after temporal artery biopsy. (1985). Mayo Clinic Proceedings, Vol. 60, No. 8, (Aug 1985), p. 538, ISSN 0025-6196

Hall, S., Persellin, S., Lie, JT., O'Brien, PC., Kurland, LT. \& Hunder GG. (1983). The therapeutic impact of temporal artery biopsy. Lancet, Vol. 2, No. 8361, (Nov 1983), pp. 1217-20, ISSN 0140-6736

Houtman, P., Doorenbos, B., Dol, J. \& Bruyn, G. (2008). Doppler ultrasonography to diagnose temporal arteritis in the setting of a large community hospital. Scandinavian Journal of Rheumatology, Vol. 37, No. 4, (Jul-Aug 2008), pp. 316-8, ISSN 0300-9742

Hunder, GG., Bloch, DA., Michel, BA., Stevens, MB., Arend, WP., Calabrese, LH., Edworthy, SM., Fauci, AS., Leavitt, RY., Lie, JT., Lightfoot, RW., Masi, AT., McShane, DJ., Mills, JA., Wallace, SL. \& Zvaifler, NJ. (1990). The American College of Rheumatology 1990 criteria for the classification of giant cell arteritis. Arthritis and Rheumatism, Vol. 33, No. 8, (Aug 1990), pp. 1122-8, ISSN 0004-3591

Hunder, GG. Clinical features of GCA/PMR. (2000). Clinical and Experimental Rheumatology, Vol. 18, No. 4, Suppl 20, (Jul-Aug 2000), pp. S6-8, ISSN 0392-856X

Karahaliou, M., Vaiopoulos, G., Papaspyrou, S., Kanakis, MA., Revenas, K. \& Sfikakis PP. (2006). Colour duplex sonography of temporal arteries before decision for biopsy: a prospective study in 55 patients with suspected giant cell arteritis. Arthritis Research \& Therapy, Vol. 8, No. 4, (2006), R116, ISSN 1478-6362

Karassa, FB., Matsagas, MI., Schmidt, WA. \& Ioannidis, JP. (2005). Meta-analysis: test performance of ultrasonography for giant-cell arteritis. Annals of Internal Medicine, Vol. 142, No. 5, (Mar 2005), pp. 359-69, ISSN 1539-3704 
Kelley JS. (1978). Doppler ultrasound flow detector used in temporal artery biopsy. Archives of Ophthalmology, Vol. 96, No. 5, (May 1978), pp. 845-6, ISSN 0003-9950

Kissin, EY. \& Merkel, PA.(2004). Diagnostic imaging in Takayasu arteritis. Current Opinion in Rheumatology, Vol. 16, No. 1, (Jan 2004), pp. 31-7, ISSN 1040-8711

Kolossvary, E., Kollar, A., Pinter, H., Erényi, E., Kiséry, I., Péter, H., Farkas, K., Mogán, L., Farsang, C. \& Kiss I. (2005). Bilateral axillobrachial and external carotid artery manifestation of giant cell arteritis: important role of color duplex ultrasonography in the diagnosis. International Angiology, Vol. 24, No. 2, (Jun 2005), pp. 202-5, ISSN 0392-9590

LeSar, CJ., Meier, GH., DeMasi, RJ., Sood, J., Nelms, CR., Carter, KA., Gayle, RG., Parent, FN. \& Marcinczyk MJ. (2002). The utility of color duplex ultrasonography in the diagnosis of temporal arteritis. Journal of Vascular Surgery, Vol. 36, No. 6, (Dec 2002), pp. 1154-60, ISSN 0741-5214

Maldini, C., Depinay-Dhellemmes, C., Tra, TT., Chauveau, M., Allanore, Y., Gossec, L., Terrasse, G., Guillevin, L., Coste, J. \& Mahr A. (2010). Limited value of temporal artery ultrasonography examinations for diagnosis of giant cell arteritis: analysis of 77 subjects. Journal of Rheumatology, Vol. 37, No. 11, (November 2010), pp. 232630, ISSN 0315-162X

Morinobu, A., Tsuji, G., Kasagi, S., Saegusa, J., Hayashi, H., Nakazawa, T., Kogata, Y., Misaki, K., Nishimura, K., Sendo, S., Miura, N., Kawano, S. \& Kumagai S. (2011). Role of imaging studies in the diagnosis and evaluation of giant cell arteritis in Japanese: report of eight cases. Modern Rheumatol, [Epub ahead of print], ISSN 1439-7609

Murgatroyd, H., Nimmo, M., Evans, A. \& MacEwen, C. (2003) The use of ultrasound as an aid in the diagnosis of giant cell arteritis: a pilot study comparing histological features with ultrasound findings. Eye (Lond), Vol. 17, No. 3, (April 2003), pp. 4159, ISSN 0950-222X

Narvaez, J., Narvaez, JA., Nolla, JM., Sirvent, E., Reina, D. \& Valverde, J. (2005). Giant cell arteritis and polymyalgia rheumatica: usefulness of vascular magnetic resonance imaging studies in the diagnosis of aortitis. Rheumatology (Oxford), Vol. 44, No. 4, (April 2005), pp. 479-83, ISSN 1462-0324

Nesher, G., Shemesh, D., Mates, M., Sonnenblick, M. \& Abramowitz, HB. (2002). The predictive value of the halo sign in color Doppler ultrasonography of the temporal arteries for diagnosing giant cell arteritis. Journal of Rheumatology, Vol. 29, No. 6, (June 2002), pp. 1224-6, ISSN 0315-162X

Nesher, G., Berkun, Y., Mates, M., Baras, M., Rubinow, A. \&, Sonnenblick, M. (2004). Lowdose aspirin and prevention of cranial ischemic complications in giant cell arteritis. Arthritis \& Rheumatism, Vol. 50, No. 4, (April 2004), pp. 1332-7, ISSN 0004-3591

Perez Lopez, J., Solans Laque, R., Bosch Gil, JA., Molina Cateriano, C., Huguet Redecilla, P. \& Vilardell Tarres, M. (2009). Colour-duplex ultrasonography of the temporal and ophthalmic arteries in the diagnosis and follow-up of giant cell arteritis. Clinical and Experimental Rheumatology, Vol. 27, No. 1, Suppl. 52, (January-February 2009), pp. S77-82, ISSN 0392-856X

Pfadenhauer, K. \& Weber, H. (2003). Duplex sonography of the temporal and occipital artery in the diagnosis of temporal arteritis. A prospective study. Journal of Rheumatology Vol. 30, No. 10, (October 2003), pp. 2177-81, ISSN 0315-162X 
Puechal, X., Chauveau, M. \& Menkes, CJ. (1995). Temporal Doppler-flow studies for suspected giant-cell arteritis. Lancet, Vol. 345, No. 8962, (June 1995), pp. 1437-8, ISSN 0140-6736

Rao,JK., Allen, NB. \& Pincus, T. (1998). Limitations of the 1990 American College of Rheumatology classification criteria in the diagnosis of vasculitis. Annals of Internal Medicine, Vol. 129, No. 5, (September 1998), pp. 345-52, ISSN 0003-4819

Ray-Chaudhuri, N, Kine, DA., Tijani, SO., Parums, DV., Cartlidge, N., Strong, NP. \& Dayan MR. (2002) Effect of prior steroid treatment on temporal artery biopsy findings in giant cell arteritis. British Journal of Ophthalmology, Vol. 86, No. 5, (May 2002), pp. 530-2, ISSN 0007-1161

Reinhard, M., Schmidt, D., Schumacher, M. \& Hetzel, A. (2003). Involvement of the vertebral arteries in giant cell arteritis mimicking vertebral dissection. Journal of Neurology, Vol. 250, No. 8, (august 2003), pp. 1006-9, ISSN 0340-5354

Reinhard, M., Schmidt, D. \& Hetzel A. (2004). Color-coded sonography in suspected temporal arteritis-experiences after 83 cases. Rheumatology International, Vol. 24, No 6, ( November 2004), pp. 340-6, ISSN 0172-8172

Reitblat, T., Ben-Horin, CL \& Reitblat, A. (2003). Gallium-67 SPECT scintigraphy may be useful in diagnosis of temporal arteritis. Annals of Rheumatic Diseases, Vol. 62, No. 3, (march 2003), pp. 257-60, ISSN 0003-4967

Richards, BL., March, L. \& Gabriel, SE (2010). Epidemiology of large-vessel vasculidities. Best Practice \& Research Clinical Rheumatology, Vol. 24, No. 6, (December 2010), pp. 871-83, ISSN 1532-1770

RRomera-Villegas, A., Vila-Coll, R., Poca-Dias, V. \& Cairols-Castellote, MA. (2004). The role of color duplex sonography in the diagnosis of giant cell arteritis. Journal of Ultrasound in Medicine, Vol. 23, No. 11, (November 2004), pp. 1493-8, ISSN 0278-4297

Salvarani, C., Silingardi, M., Ghirarduzzi, A.., Lo Scocco, G., Macchioni, P., Bajocchi, G., Vinceti, M., Cantini, F., Iori, I. \& Boiardi L. (2002). Is duplex ultrasonography useful for the diagnosis of giant-cell arteritis? Annals of Internal Medicine, Vol. 137, No. 4, (August 2002), pp. 232-8, ISSN 1539-3704

Schmidt, WA., Kraft, HE., Volker, L., Vorpahl, K. \& Gromnica-Ihle, EJ. (1995). Colour Doppler sonography to diagnose temporal arteritis. Lancet, Vol. 345, No. 8953, (April 1995), p. 866, ISSN 0140-6736

Schmidt, WA., Kraft, HE., Vorpahl, K.., Volker, L.. \& Gromnica-Ihle, EJ. (1997). Color duplex ultrasonography in the diagnosis of temporal arteritis. New England Journal of Medicine, Vol. 337, No. 19, (Novembre 1997), pp. 1336-42, ISSN 0028-4793

Schmidt, WA. (2000). Doppler ultrasonography in the diagnosis of giant cell arteritis. Clinical Experimental Rheumatology, Vo. 18, No. 4, Suppl 20, (July-August 2000), S40-2, ISSN 0392-856X

Schmidt, WA., Natusch, A., Moller, DE., Vorpahl, K. \& Gromnica-Ihle, E. (2002). Involvement of peripheral arteries in giant cell arteritis: a color Doppler sonography study. Clinical Experimental Rheumatology, Vol. 20, No. 3, (May-June 2002), pp. 309-18, ISSN 0392-856X

Schmidt, WA. \& Gromnica-Ihle, E. (2003). Duplex ultrasonography in temporal arteritis. Annals of Internal Medicine, Vol. 138, No. 7, (April 2003), p. 609; author reply 60910, ISSN 1539-3704

Schmidt, WA. (2004). Doppler sonography in rheumatology. (2004). Best Practice \& Research Clinical Rheumatology, Vol. 18, No. 6, (December 2004), pp. 827-46, ISSN 1521-6942 
Schmidt, WA. \& Blockmans, D. (2005). Use of ultrasonography and positron emission tomography in the diagnosis and assessment of large-vessel vasculitis, Vol. 17, No. 1, (January 2005), pp. 9-15, ISSN 1040-8711

Schmidt, WA, \& Gromnica-Ihle, E. (2005). What is the best approach to diagnosing largevessel vasculitis? Best Practice \& Research Clinical Rheumatology, Vol. 19, No. 2, (April 2005), pp. 223-42, ISSN 1521-6942

Schmidt, WA. Current diagnosis and treatment of temporal arteritis. (2006), Current Treatment Options in Cardiovascular Medicine, Vol.8, No. 2, ( April 2006), pp. 14551, ISSN 1092-8464

Schmidt, WA., Seifert, A., Gromnica-Ihle, E., Krause, A. \& Natusch, A (2008), Ultrasound of proximal upper extremity arteries to increase the diagnostic yield in large-vessel giant cell arteritis. Rheumatology (Oxford), Vol. 47, No. 1, (Jnuary 2008), SSN 1462-0332

Schmidt, WA., Krause, A., Schicke, B., Kuchenbecker, J, \& Gromnica-Ihle, E. (2009). Do temporal artery duplex ultrasound findings correlate with ophthalmic complications in giant cell arteritis? Rheumatology (Oxford), Vol. 48, No. 4, (April 2009), pp. 383-5, ISSN 1462-0332

Siemssen SJ. (1987). On the occurrence of necrotising lesions in arteritis temporalis: review of the literature with a note on the potential risk of a biopsy. British Journal of Plastic Surgery, vol. 40, No. 1, (Jauary 1987), pp. 73-82, ISSN 0007-1226

Slavin, ML. (1986). Brow droop after superficial temporal artery biopsy. Archives of Ophthalmology, Vol. 104, No. 8, (Augut 1986), p. 1127, ISSN 0003-9950

Stanson, AW. (2000). Imaging findings in extracranial (giant cell) temporal arteritis. Clinical and Experimental Rheumatology, Vol. 18, No. 4 , Suppl 20, (Julyu-August 2000), pp. S43-8, ISSN 0392-856X

Suelves, AM., Espana-Gregori, E., Tembl, J., Rohrweck, S., Millan, JM. \& Diaz-Llopis, M. (2010). Doppler ultrasound and giant cell arteritis.Clinical Ophthalmology, Vol. 25, No. 4,(November 2010), pp. 1383-4, ISSN 1177-5483

Tato, F.\& Hoffmann U. (2006). Clinical presentation and vascular imaging in giant cell arteritis of the femoropopliteal and tibioperoneal arteries. Analysis of four cases. Journal of Vascular Surgery, Vol. 44, No 1, (July 2006), pp. 176-82, ISSN 0741-5214

Tato, F. \& Hoffmann U. Giant cell arteritis: a systemic vascular disease. (2008). Vascular Medicine, Vol. 13, No. 2, (2008), pp. 127-40, ISSN 1358-863X

Vinckier, L., Hatron, PY., Gadenne, C.," Catteau, MH., Gosset, D.\& Devulder, B. (1989). Significance of arterial Doppler in Horton's disease. Prospective study of 59 case reports. Journal des Maladies Vasculaires, Vol. 14, Suppl C, (1989), ISSN 0398-0499

Walter, MA., Melzer, RA., Schindler, C., Muller-Brand, J., Tyndal,l A \& Nitzsche EU (2005). The value of [18F]FDG-PET in the diagnosis of large-vessel vasculitis and the assessment of activity and extent of disease. European Journal of Nuclear Medicine and Molecular Imaging, Vol. 32, No. 6, (june 2005), pp. 674-81, ISSN 1619-7070

Warrington, KJ. \& Matteson, EL. Management guidelines and outcome measures in giant cell arteritis (GCA). (2007). Clinical and Experimental Rheumatology, Vol. 25, No. 6, Suppl 47, (Novembre-December 2007), pp.137-41, 0392-856X

Weyand, CM. \& Goronzy, JJ. (2003). Giant-cell arteritis and polymyalgia rheumatica. Annals of Internal Medicine, Vol.1 39, No. 6, (September 2003), pp. 505-15, ISSN 1539-3704 


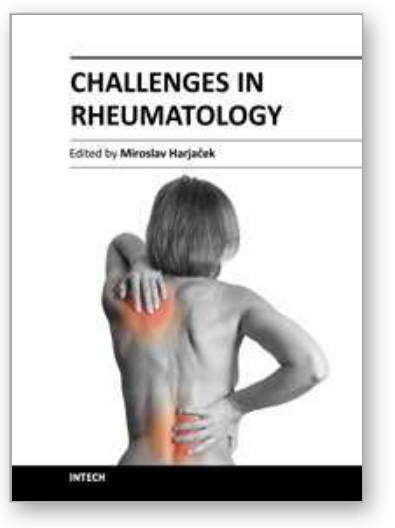

\author{
Challenges in Rheumatology \\ Edited by Dr. Miroslav Harjacek
}

ISBN 978-953-307-848-9

Hard cover, 190 pages

Publisher InTech

Published online 22, December, 2011

Published in print edition December, 2011

Rheumatology is a subspecialty of medicine that focuses on the biology, cause, diagnosis and the treatment of a variety of musculoskeletal and other systemic diseases. The field of rheumatology is expanding rapidly and several very exciting developments have occurred during the recent years. Firstly, there has been a new dramatic understanding of the nature of inflammation and the possibility of specifically regulating the aberrant immune inflammatory response. Secondly, an understanding of pathogenesis has lead to the development of new, more targeted therapies. Challenges in Rheumatology has assembled an impressive group of international experts who have studied specific aspects of certain rheumatic diseases and have extensive experience either in pathophysiology, or with the in-depth diagnosis and/or management of rheumatic patients. They communicate their knowledge and experience to the reader in chapters that are conveniently organized as pathophysiology, clinical manifestations and diagnosis of selected rheumatic diseases, medical and perioperative orthopedic management, and the economic impact of rheumatic diseases. We hope that this book will help trainees become better physicians and scientists, and that it will help practicing rheumatologists to provide better care, and ultimately, improve the quality of life of our patients.

\title{
How to reference
}

In order to correctly reference this scholarly work, feel free to copy and paste the following:

Giovanni Ciancio, Marco Bruschi and Marcello Govoni (2011). Ultrasonography in Diagnosis and Follow-Up of Temporal Arteritis: An Update, Challenges in Rheumatology, Dr. Miroslav Harjacek (Ed.), ISBN: 978-953-307848-9, InTech, Available from: http://www.intechopen.com/books/challenges-in-rheumatology/ultrasonographyin-diagnosis-and-follow-up-of-temporal-arteritis-an-update

\section{INTECH}

open science | open minds

\section{InTech Europe}

University Campus STeP Ri

Slavka Krautzeka 83/A

51000 Rijeka, Croatia

Phone: +385 (51) 770447

Fax: +385 (51) 686166

www.intechopen.com

\section{InTech China}

Unit 405, Office Block, Hotel Equatorial Shanghai

No.65, Yan An Road (West), Shanghai, 200040, China

中国上海市延安西路 65 号上海国际贵都大饭店办公楼 405 单元

Phone: +86-21-62489820

Fax: $+86-21-62489821$ 
(C) 2011 The Author(s). Licensee IntechOpen. This is an open access article distributed under the terms of the Creative Commons Attribution 3.0 License, which permits unrestricted use, distribution, and reproduction in any medium, provided the original work is properly cited. 